\title{
幼儿家长家庭教育观念:现状及问题探索构架
}

杨丽

山东省泰安市泰山区直属机关幼儿园

DOI:10.32629/jief.v2i11.2515

[摘 要] 家庭教育观念在当前是一个新的概念, 具有非常明显的时代性特点, 对儿童的发展来说, 能够起到非常重要的影响, 对其也有非常 重要的作用。本文对幼) 七的家庭教育观念对儿童发展的影响进行了具体的探讨，对家里教育观念中主要的内容教育观、发展观、亲子观进行 了具体的分析，对当前我国幼儿家长的家庭教育观念存在的问题以及现状进行分析，同时提出一定的建议对其进行转变和改善。

[关键词] 幼儿家长; 家庭教育观念; 问题

中图分类号：G613 文献标识码：A

家庭教育观念是一种全新的概念, 受到社会发展以及时代变化的影 响, 具有非常明显的时代性, 传统的家庭教育观念与现代的家庭教育观 念有二在非常明显的差异。家庭教育观念也就是指家长或是父母的教育 观念, 也就是说家长或是父母在对子女进行培养的过程中，对子女未来 的发展和子女如何进行发展所抱有的整体、基本的观念。家庭教育观念 中的具体内容, 研究人员的不同观点也就会随之而变化。

\section{1 幼儿家长家庭教育观念现状及问题}

1.1 缺乏正确的儿童观, 儿童还不被作为独立的个体

在传统的教育观念中, 权威型家长和家长制的作风受到了推崇, 在 进行家庭教育的过程中, 以父母或是家长的想法来对儿童进行教育, 以 此来达到高教育的目标, 这也使孩子成为家长意愿的替代品、孩子体现 的是家长的自身愿望、孩子教育的结构成为了家长强制出的产品, 这也 是最为传统的亲子观。

1.2 幼儿家长对有些问题的重要性认识不到

传统的教育观念中, 普遍运用的教育方法是灌输式、教育目标也不 是子女的实际想法, 教育的内容也重智轻德, 对于这些来说, 现代的教 育观将教育非万能论作为基础，对教育的有效性、教育的原则、学校教 育、社会教育以及家庭教育之间的作用更加的重视，在对教育方法、教 育任务、教育目标进行设立的过程中, 也更加的突出了以儿童为本、以 儿童的健康发展为本这些理念。

1.3 幼儿家长对家庭教育观念的全面性认识不深

儿童观与儿童发展观两者是相辅相成的, 彼此之间互为基础。儿童 观必须要在对儿童的本质特点有全面的了解和认识的基础上，对儿童身 心的发展规律和特点进行分析, 遵循以儿童为本的基本原则。儿童发展 观要将儿童观作为基础, 还必须要满足三个要求:第一, 对儿童的发展主 体胜尊重并且承认; 第二, 对儿童的发展潜能尊重并承认; 第三, 对儿 童的发展差异性尊重并承认。在我国传统家庭教育观念中, 受到一些错 误儿童观的影响, 儿童发展现就容易变为以家长的愿望为基础, 以家长 的意愿为主体。

\section{2 对我国当前幼儿家长的家庭教育观念进行有效的改善}

2.1 构建国家级的家庭教育指导机构

当前, 我国对家庭教育进行指导的结构主要以妇联组织以及部分专 业的学会为中心, 对各种资源并没有进行有效的整合。政府需要对学术
资源、行政力量以及资金资源进行有效的组织，进行协同同坐，构建一 个中国的家庭教育指导的权威性机构, 主要负责对全国的亲子教育方案 进行推行、研发、指导以及评估，以此来对亲子教育的实践工作进行引 导。

2.2 对图书和电视等传媒子单元进行规范和引导

当前, 家长进行家庭教育知识学习的主要方式仍然还是要通过报纸、 图书以及电视。所以, 政府可以采取一定的方式, 使得传统媒体对亲子 教育方面的内容的系统性和科学性进行有效的提高, 对网络等现代化的 媒体进行充分的利用, 以此来使亲子教育的受众面和覆盖面都得到提升。

2.3 鼓励幼儿园开展亲子教育课程

幼儿园是对家长培训活动进行开展的另一个渠道。当前, 幼儿园由 于受到自身资源的限制, 在开展家庭教育活动的时候对外部的资源过度 的依赖, 也就是对校外的专家依赖过大。幼儿园由于对一些专家教授进 行邀请过于的重视, 而进行家庭教育活动所讲的主体也是由这些专家和 教育随意决定的, 这也就导致了学校全部家长的教育内容随意性较强, 没有自主性、计划性以及系统性。为了使幼儿园的家庭教育指导的针对 性和系统性能够得到有效的提高, 就必须要将幼儿园中具有实际经验的 教师作为教育的主体, 将外部专家作为顾问进行指导, 让外部专家能够 给予主讲教师一定帮助, 让教师能够对教育的内容和形式不断的进行完 善, 建设出亲子教育的体系。

\section{3 结语}

家庭教育观念在当前是一个新的概念, 具有非常明显的时代性特点, 对儿童的发展来说, 能够起到非常重要的影响, 对其也有非常重要的作 用。本文对家庭教育观念的现状和问题进行了具体的分析, 同时提出了 对家庭教育观念进行更新和改善的具体方法, 希望能够为日后的研究提 供一些帮助。

\section{[参考文献]}

[1]刘秀丽,刘航.幼儿家长家庭教育观念:现状及问题[J].东北师大学 报(哲学社会科学版),2009,05:192-195.

[2]王丽. 论农村地区幼儿家庭教育指导 [J]. 内江师范学院学 报,2014,2905:117-121.

[3]刘亚男.家庭与幼儿心理教育 [J].百科知识,2020(27):81-82. 